\title{
Health-Related Quality of Life in patients with hepatitis $C$ in double and triple therapy*
}

\section{Qualidade de vida relacionada à saúde em pacientes com hepatite C em terapia dupla e tripla Calidad de vida relacionada con la salud en pacientes con hepatitis $\mathrm{C}$ en terapia doble y triple}

Raíssa Neves Fagundes ${ }^{1}$, Lincoln Eduardo Villela Vieira de Castro Ferreira ${ }^{1}$, Fábio Heleno de Lima Pace ${ }^{1}$

* Extracted from the dissertation "Avaliação da qualidade de vira relacionada à saúde em pacientes com hepatite crônica $\mathrm{C}$ tratados com terapia dupla e tripla," Universidade Federal de Juiz de Fora, 2015.

${ }^{1}$ Universidade Federal de Juiz de Fora,

Departamento de Gastroenterologia, Juiz de Fora, MG, Brazil

\section{ABSTRACT}

Objective: Comparing Health-Related Quality of Life (HRQoL) scores in patients with chronic hepatitis $\mathrm{C}$ undergoing double and triple antiviral therapy and analyzing possible factors related to HRQoL. Method: HRQoL was assessed using the Short Form 36 and Chronic Liver Disease Questionnaire, which were applied at baseline and at weeks 4, 12 and 16 of treatment to 32 patients divided into two groups: double therapy with pegylated interferon (IFN-PEG) and ribavirin, and triple therapy with PEG-IFN, ribavirin and telaprevir. Results: The reduction of HRQoL was greater in patients receiving triple therapy compared to those treated with two drugs, the most critical time is at 12 weeks in both groups. After removal of telaprevir, the triple therapy group significantly improved their HRQoL scores. Anxiety and depression before treatment, employment status and race are significantly related to diminished HRQoL. Conclusion: Patients undergoing double and triple therapy have diminished HRQoL indexes, but the addition of telaprevir chooses a more significant decrease.

\section{DESCRIPTORS}

Hepatitis C; Quality of Life; Combined Modality Therapy; Ribavirin; Interferons; Protease Inhibitors. 


\section{INTRODUCTION}

Approximately $1.5 \%$ of the world population is chronically infected by the Hepatitis C Virus $(\mathrm{HCV})^{(1-3)}$. In addition to its high prevalence, chronic Hepatitis $\mathrm{C}$ is a leading cause of liver cirrhosis, hepatocellular carcinoma and liver transplant indications worldwide ${ }^{(4-5)}$.

Recently in Brazil, new drugs have become available for treating chronic hepatitis $\mathrm{C}$, namely direct action antivirals such as telaprevir (TVR) and boceprevir (BOC). They are recommended for patients with genotype 1 and advanced fibrosis. If, on the one hand there has been a $30 \%$ increase in sustained virological response (SVR) rates ${ }^{(6)}$, on the other, the frequency and severity of adverse events have significantly increased ${ }^{(6-8)}$.

Lately, Health-Related Quality of Life (HRQoL) has gained prominence as a tool to assess the impact of chronic diseases and their treatments on the perception of health and patient well-being ${ }^{(4,9-10)}$. For this purpose, Short Form 36 (SF-36), a generic instrument, and Chronic Liver Disease Questionnaire (CLDQ), which is specifically for HRQoL analysis in patients with chronic liver disease, have been used ${ }^{(11)}$.

Studies have shown that untreated patients with chronic hepatitis $\mathrm{C}$ and those undergoing antiviral therapy with pegylated interferon (PEG-IFN) and ribavirin present significant diminished quality of life indices ${ }^{(4,9-10,12-13)}$. However, in Brazil there is the perspective of providing more effective drugs and with fewer adverse events, and triple therapy with telaprevir will possibly remain as a therapeutic option. Therefore, the aim of this study was to assess HRQoL scores in patients with chronic hepatitis $\mathrm{C}$ undergoing double (PEG-IFN and RBV) and triple therapy (PEG-IFN, RBV and TVR) and to identify possible factors involved in the perception of HRQoL.

\section{METHOD}

A prospective cohort observational study which included patients aged between 18 and 75 years and who had a diagnosis of chronic hepatitis $\mathrm{C}$ established by the presence of HCV in RNA serum carried out by the Polymerase Chain Reaction - Real Time (RT-PCR) technique with antiviral therapy indication as per the recommendations of the Clinical and Therapeutic Protocol Guidelines for Viral Hepatitis C of the Brazilian Ministry of Health, 2013, Decree number 221 from July, $13^{\text {th }} 2011$ - SVS/MS ${ }^{(14)}$. Genotyping was performed by the same procedure and both tests were performed at Fundação Ezequiel Dias, Belo Horizonte. All patients were on regular follow-up in the Reference Center for Viral Hepatitis at the University Hospital Gastroenterology Service of the Universidade Federal de Juiz de Fora (HU-UFJF), in the period from March 2012 to July 2014. All medications are offered free by the Unified Brazilian Health System (SUS).

Patients under 18 or over 75 years of age, those infected with the human immunodeficiency virus (HIV), Hepatitis $\mathrm{B}$ virus $(\mathrm{HBV})$ and chronic kidney disease (creatinine greater than $1.5 \mathrm{mg} / \mathrm{dL}$ ) were excluded.
According to the protocol of the Brazilian Ministry of Health (2013), patients infected with genotype 1 with grade 3 or 4 liver fibrosis should receive triple therapy, and double therapy for the remaining others. Double therapy consists in the use of PEG-IFN alpha 2a (180 micrograms) or 2b (1.5 micrograms $/ \mathrm{kg}$ of body weight) along with ribavirin $1000 \mathrm{mg}(<75 \mathrm{~kg})$ and $1250 \mathrm{mg} /$ day $(\geq 75 \mathrm{~kg})$, once a week. Treatment duration is 24 weeks for genotype 2 or 3 , and 48 weeks for genotype 1 . In addition to PEG-IFN and RBV, the triple therapy group received telaprevir (TPV) at a dose of $1.125 \mathrm{mg}$ twice day for the first 12 weeks, followed by double therapy until the end of treatment ${ }^{(14)}$. All patients were followed up to 16 weeks of treatment, since the aim of the study was to determine the influence of telaprevir on HRQoL indexes, and what differs between both groups up to the $12^{\text {th }}$ week of treatment is the presence of telaprevir. To check the behavior of HRQoL scores after the withdrawal of telaprevir, a new evaluation of HRQoL was performed 4 weeks after its suspension (at 16 weeks). Clinical follow-ups were conducted according to the CRHV routine of the HU-UFJF. According to therapeutic guidelines of the Ministry of Health, new determinations of $\mathrm{HCV}$ viral load were conducted at weeks 4 and 12 . A negative $\mathrm{HCV}$ viral load at week 4 was considered as a rapid virological response (RVR), and for patients on triple therapy, rapid virological response extended to negative $\mathrm{HCV}$ viral load at weeks 4 and 12 . The criteria for therapy discontinuation were based on the recommendations of the Ministry of Health protocol.

Prior to the start of therapy, sociodemographic variables (gender, age, race, marital status, employment status, education level, smoking, alcohol consumption), laboratory variables (genotype, HCV viral load, hemoglobin levels), and histological information (degree of liver fibrosis according to the METAVIR Scale, 1996) were collected through clinical consultation carried out by the assistant team and an interview conducted by the researcher.

At baseline, and at weeks 4,12 and 16 of treatment, anxiety and depression were screened through the application of the Hospital Anxiety and Depression Scale (HADS) using the translated and validated version for the Brazilian population. HADS consists of 14 items, seven for anxiety identification (HADS-A) and seven for depression symptoms (HADS-D), and it only takes into account psychological symptoms. A depression episode was considered for patients with HADS-D $>8$ and HADS-A $>8^{(15)}$.

In order to assess HRQoL, all study participants responded to the Short Form 36 (SF-36) and to the Chronic Liver Diseases Questionnaire (CLDQ). The questionnaires were applied in Portuguese at baseline and at weeks 4, 12 and 16 of therapy. Assistant staff was blinded to the results of applied scores. SF-36 is a generic instrument universally used to assess HRQoL ${ }^{(16-17)}$. SF-36 questionnaire consists of 11 questions and 36 items covering eight domains: physical functioning, physical aspects, bodily pain, general health perceptions, vitality, social functioning, emotional functioning and mental health. For data analysis, the eight domains were grouped into two major components: Physical Com- 
ponent Summary (PCS) and Mental Component Summary (MCS). The individual received a score in each domain, ranging from 0 to 100 , with 0 being the worst and 100 the best ${ }^{(17)}$. CLDQ is specific to assess HRQoL in patients with chronic liver disease. It consists of 29 items divided into six domains: abdominal symptoms, fatigue, systemic symptoms, activity, emotional function and worry. The scores calculated for each domain ranged from 1 to 7 . Higher scores indicated a minimum frequency of symptoms, and hence a better HRQoL. Total score is calculated based on the average of all 29 items $^{(18)}$.

Statistical analysis was performed using SPSS 16.0 (SPSS, Chicago, IL). Non-parametric variables were expressed as median and those with normal distribution as mean \pm standard deviation (SD). Descriptive statistics of all the relevant variables for the two groups were calculated. For data analysis, HRQoL indexes were compared among double and triple therapy groups. Independent t-test was used to compare the difference of means at each moment of therapy. Multivariate linear regression model was used to identify factors independently associated to HRQoL. Regression analysis of the variables in the correlation analysis that had $\mathrm{p}<0.15$ were included. For comparison, the level of significance was $\mathrm{P}<0.05$.

The study protocol was approved by the Ethics Committee Research of HU-UFJF, Brazil, CAAE 01601512.6.0000.5133.

\section{RESULTS}

32 patients were included, being 17 treated with double therapy (INF + RIB) and 15 with triple therapy (INF + RIB + TEL). Most patients were female (59\%) and 25\% were married. There was a predominance of genotype 1 (75\%) and liver cirrhosis was present in 34\% of patients. The comparative analysis between the two groups showed no difference in terms of sociodemographic characteristics, such as gender, race, marital status, education, professional status, smoking or alcohol consumption, which shows homogeneity between groups.

\section{HRQOL ACCORDING SF-36}

At baseline, the average of Physical Component Summary (PCS) from SF-36 was similar in the double and triple therapy groups $(51.5 \pm 8.4$ vs. $53.8 \pm 6.0 ; \mathrm{p}=0.413)$. After the start of treatment, HRQoL scores declined in both groups, but in the triple therapy group the reduction was more pronounced. At week 12, the PCS average was worse in patients treated with three drugs $(27.7 \pm 4.06$ vs. $37.6 \pm 8.23 ; \mathrm{p}<0.001)$. At week 16, four weeks after telaprevir discontinuation, there was a recovery of PCS scores, however, they still remained lower in the triple therapy group $(35.0 \pm 3.66$ vs. $40.8 \pm 9.33 ; \mathrm{p}=0.026)$. Comparing the differences (decrease) between the contents of the PCS before treatment and at week $12(-26.03 \pm 8.11$ vs. $-11.88 \pm 10.65 ; \mathrm{p}<0.001)$ there was a greater reduction observed in the triple therapy patients (Figure 1). Among the PCS domains, physical functioning $(\mathrm{PF})$ was the most compromised in the triple compared to double therapy, at weeks $4(34.66 \pm 2.85$ vs. $64.17 \pm 2.39 ; \mathrm{p}=0.003)$ and week 12 (17.06 \pm 1.60 vs. $59.52 \pm 2.64 ; \mathrm{p}<0.001)$. At week 16 , four weeks after the withdrawal of telaprevir, physical functioning $(\mathrm{PF})$ became similar between the groups (55.82 \pm 2.58 vs. $45.53 \pm 1.03$; $\mathrm{p}=0.144)$.

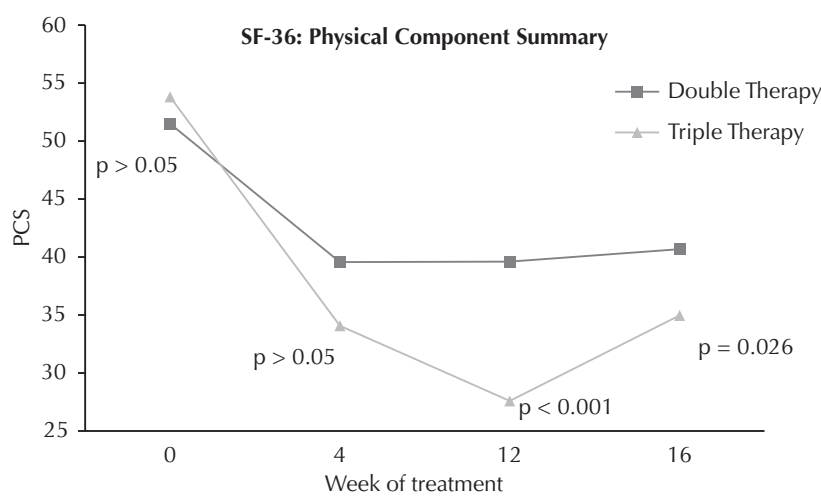

Figure 1 - Physical Component Summary (PCS) during the 16 weeks of treatment, SF-36 - Juiz de Fora, MG, Brazil, 2014.

At baseline, the Mental Components Summary (MCS) of the SF-36 were similar in both groups (60.1 \pm 3.80 vs. $55.1 \pm 9.11 ; \mathrm{p}=0.067)$. At weeks 4 and 12 , MCS scores were similar, but at week 16, the average MCS was lower in patients undergoing triple therapy $(36.2 \pm 5.46$ vs. $46.4 \pm 1.19$; $\mathrm{p}=0.004)$ (Figure 2). Among MCS domains, vitality (VIT) was the most affected. The average for the VIT domain was significantly lower in patients on triple therapy at weeks 4 $(26.93 \pm 1.04$ vs. $52.64 \pm 3.09 ; \mathrm{p}=0.004)$ and $12(23.66 \pm$ 1.90 vs. $51.76 \pm 2.76 ; p=0.002)$. At week 16 , four weeks after the withdrawal of telaprevir, the VIT scores were similar in both groups $(46.53 \pm 9.97$ vs. $53.82 \pm 2.94$; $\mathrm{p}=0.348)$. The difference (increase) in VIT rates at week 16 compared to week 12 was significantly higher in patients treated with three drugs $(22.86 \pm 2.44$ vs. $2.95 \pm 2.26 ; \mathrm{p}=0.015)$.

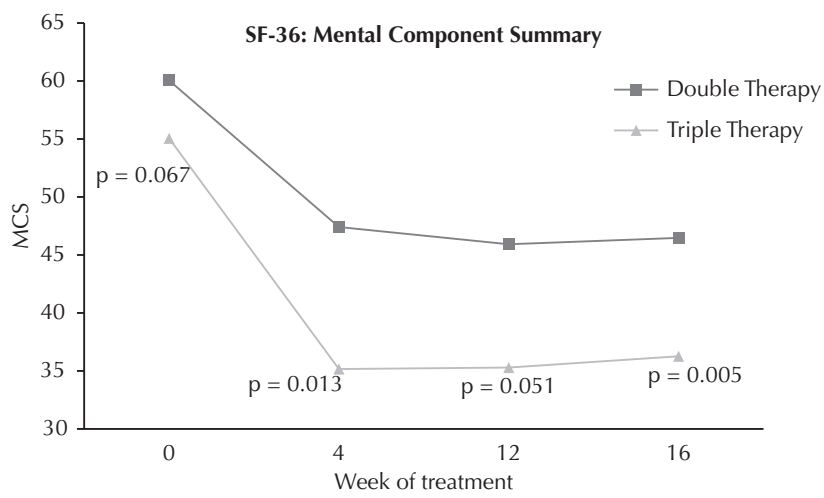

Figure 2 - Mental Component Summary (MCS) during the 16 weeks of treatment, SF-36 - Juiz de Fora, MG, Brazil, 2014.

When analyzing the domains individually, week 12 showed the worst scores of HRQoL. Physical functioning $(\mathrm{PF})(17.06 \pm 1.60$ vs. $59.52 \pm 2.64 ; \mathrm{p}<0.001)$, physi$\mathrm{cal}$ aspects $(\mathrm{PA})(0.00 \pm 0.00$ vs. $30.82 \pm 3.7 ; \mathrm{p}=0.003)$, bodily pain $(31.96 \pm 2.83$ vs. $61.17 \pm 2.84 ; \mathrm{p}=0.007)$, vitality (VIT) $(23.66 \pm 1.90$ vs. $51.76 \pm 2.76 ; \mathrm{p}=0.002)$, social functioning $(\mathrm{SF})(37.53 \pm 2.840$ vs. $73.79 \pm 3.43 ; \mathrm{p}=0.003)$, 
emotional functioning $(\mathrm{EF})(21.66 \pm 3.88$ vs. $56.70 \pm 4.95$; $\mathrm{p}=0.033)$ and mental health $(\mathrm{MH})(42.16 \pm 2.11$ vs. 61.58 $\pm 2.66 ; \mathrm{p}=0.031)$ were significantly worse in the triple therapy group.

\section{HRQOL ACCORDING TO CLDQ}

At baseline, total CLDQ score was similar in both groups $(6.30 \pm 0.55$ vs. $6.20 \pm 0.86 ; p=0.69)$. However, during treatment scores were significantly worse in the triple therapy group at 4 weeks $(5.29 \pm 1.02$ vs. $3.96 \pm 0.81 ; \mathrm{p}$ $<0.001)$ and 12 weeks $(4.97 \pm 1.00$ vs. $3.40 \pm 1.19$; $\mathrm{p}<0.001)$. At week 16, four weeks after discontinuation of telaprevir, the scores remained worse in the triple therapy group (5.28 \pm 1.08 vs. $4.25 \pm 0.89 ; \mathrm{p}=0.007$ ) (Figure 3 ).

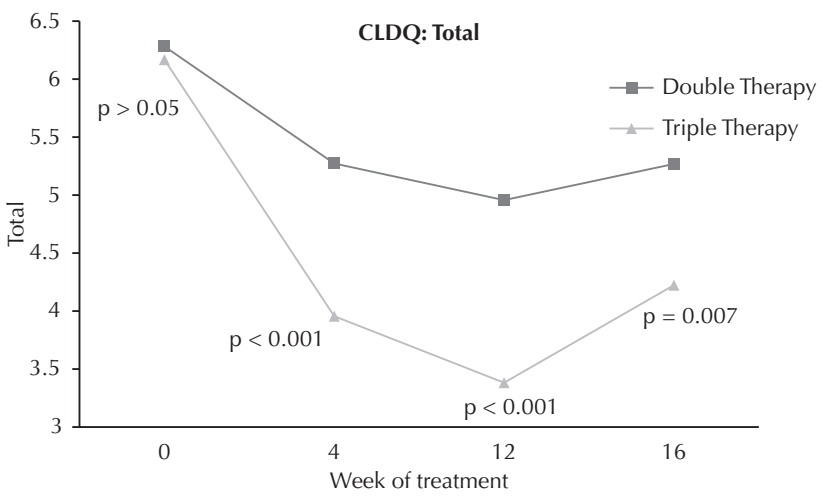

Figure 3 - CLDQ - TOTAL during the 16 weeks of treatment - Juiz de Fora, MG, Brazil, 2014.

Fatigue (FAT) was the CLDQ domain most affected in patients on triple therapy at weeks $4(2.77 \pm 1.19$ vs. 4.78 $\pm 1.39 ; \mathrm{p}<0.001), 12$ ( $2.20 \pm 0.83$ vs. $4.54 \pm 1.81 ; \mathrm{p}<0.001)$ and $16(3.53 \pm 1.12$ vs. $4.64 \pm 1.63 ; \mathrm{p}=0.038)$. In comparing the differences (decrease) between the total scores of the CLDQ obtained before treatment vs. week 12, the reduction observed was greater in the triple treatment group $(-2.07 \pm 1.22$ vs. $-1.33 \pm 1.31, \mathrm{p}=0.003)$.

Week 12 of treatment was the worst with respect to CLDQ scores. Abdominal symptoms (AS) $(3.83 \pm 2.21$ vs. $5.67 \pm 1.58 ; p=0.011)$, fatigue (FAT) $(2.20 \pm 0.83$ vs. 4.54 $\pm 1.81, \mathrm{p}<0.001)$, systemic symptoms (SS) $(2.75 \pm 0.90$ vs. $4.59 \pm 1.19 ; \mathrm{p}<0.001)$, activity (ACT) $(2.86 \pm 1.63$ vs. 4.73 $\pm 1.49 ; \mathrm{p}=0.002)$, emotional function $(\mathrm{EF})(3.10 \pm 1.80 \mathrm{vs}$. $4.96 \pm 1.59 ; \mathrm{p}=0.004)$, worry $(\mathrm{WOR})(5.16 \pm 1.60$ vs. 6.47 $\pm 0.79 ; \mathrm{p}=0.009)$ and total $(\mathrm{TT})(4.97 \pm 1.00$ vs. $3.40 \pm$ $1.19 ; \mathrm{p}<0.001)$ domains were significantly lower in patients on triple therapy.

\section{IDENTIFYING HRQOL PREDICTORS - SF 36 AND CLDQ}

With predictors of quality of life, it became evident that triple therapy was independently associated with lower HRQoL by both the SF-36 and the CLDQ. Regarding the SPC, only the triple treatment was associated with diminished HRQoL $(\beta=-0.680, p<0.001)$. The presence of anxiety $(\beta=-0.602, p<0.001)$ and depression $(\beta=-0.571$, $\mathrm{p}=0.001)$ before treatment and employment status $(\beta=$ $0.425, \mathrm{p}=0.0015)$ was associated with the SMC. Accord- ing to $C L D Q$, anxiety $(\beta=-0.592, p<0.001)$, depression $(\beta=-0.614, p<0.001)$, triple therapy $(\beta=-0.593, p<0.001)$, race $(\beta=0.360, p=0.043)$ and employment status $(\beta=0.356$, $p=0.045)$ were predictors of HRQoL. The decline of HRQoL scores according to the CLDQ questionnaire was associated with a higher chance of obtaining rapid virological response (RVR) $(\beta=0.388, p=0.028)$, being higher in the triple therapy group ( $93.3 \%$ vs. $47.1 \%$; $\mathrm{p}=0.003)$.

\section{DISCUSSION}

In recent years, the treatment of chronic hepatitis $\mathrm{C}$ has substantially evolved with the introduction of more effective drugs with fewer adverse events. In Brazil, the standard treatment for patients with HCV genotype 1 and advanced fibrosis is triple therapy with protease telaprevir and boceprevir inhibitors. In addition to efficacy and safety, quality of life measures are important parameters to be determined during antiviral therapy and increasingly valued for selecting the most appropriate treatments.

It is known that chronic hepatitis $\mathrm{C}$ causes a decline in HRQoL indexes, even without advanced liver disease ${ }^{(19-20)}$. In a systematic review including 15 studies, patients with chronic hepatitis $\mathrm{C}$ without signs of advanced disease declined in HRQoL of the SF-36 in both physical and mental component summary ${ }^{(21)}$. As expected in patients with liver cirrhosis, the HRQoL reduction is even greater ${ }^{(22-23)}$. Until recently, the standard therapy of chronic hepatitis $C$ was a PEG-IFN and ribavirin combination. However, this treatment is associated with a number of adverse effects such as fatigue, influenza-like symptoms (flu-like), anemia, and neuropsychiatric disorders that affect quality of life and eventually lead to discontinuation of therapy. A study of 1860 patients with chronic hepatitis C treated with PEGIFN and ribavirin showed a reduction in quality of life scores from SF-36 ${ }^{(24)}$. Studies evaluating the quality of life in patients undergoing double therapy are scarce and triple therapy even scarcer.

In our study, it was demonstrated that patients treated with three drugs (telaprevir) had a greater reduction in quality of life indexes. According to the SF-36, the most significant decrease was in the PCS, specifically in functional capacity. It was noted that week 12 was the most critical, and at week 16, four weeks after the withdrawal of telaprevir, there was a recovery of HRQoL, but it still remained lower in comparison to patients on double therapy. This fact clearly shows that telaprevir is responsible for these findings. Although this study has the limitation of not having evaluated the association between anemia and HRQoL, it is possible that the lower HRQoL rates observed in patients on triple therapy can be justified by its presence. The treatment of patients with double therapy is associated with the development of dose-dependent hemolytic anemia induced by ribavirin. The addition of telaprevir increases the incidence of anemia, as was shown in one study in which $30 \%$ and $15 \%$ of patients treated with triple therapy (PEG-IFN + ribavirin + telaprevir) and double therapy developed anemia, respectively ${ }^{(25)}$. In a study published evaluating the safety of telaprevir in 1782 
patients with advanced liver fibrosis, anemia was present in 931 (59\%) patients and 157 (10\%) patients required blood transfusions ${ }^{(26)}$. Another study reported that $90 \%$ of 2084 patients treated with triple therapy in the US experienced adverse events, requiring some intervention and 39\% of patients discontinued therapy prematurely ${ }^{(27)}$. It is possible that such events have also contributed to the diminished HRQoL observed in this study.

Regarding MCS, the reduction was only higher in patients undergoing triple therapy at week 16. Adverse events on neuropsychological functions during antiviral therapy are mainly related to Interferon, and the addition of telaprevir might not enhance such effects, which may explain this finding.

According to CLDQ, the behavior of quality of life scores was very similar to that observed with the SF-36, showing good concordance between the questionnaires. It was worse in patients on triple therapy at weeks 4 and 12 with partial recovery at week 16 , but remained worse at this point when compared to patients on double therapy. In both questionnaires week 12 was critical, during which we observed the lowest levels of HRQoL. Similarly, other studies showed lower levels of HRQoL at week 12 of treatment with double therapy ${ }^{(24,28)}$.

During antiviral therapy, it is important to identify factors associated with deterioration of HRQoL early on so that interventions can be made with the objective of maintaining treatment, thereby avoiding its premature interruption and failure. Treatment with three drugs was independently associated to a diminished HRQoL, which motivates the search for new drugs, which fortunately are to be made available soon in Brazil. However, it is possible that telaprevir may still remain as a therapeutic option in Brazil. In our study, the presence of anxiety and depression prior to treatment, employment status and race were associated with HRQoL. Thus, routine screening of psychiatric disorders appear to be recommended.
An important predictor of SVR is the negativity of the virus in the fourth week of treatment, corresponding to rapid virological response. As expected, RVR occurred more often in the triple therapy group (93.3\% vs. 47.1\%; $\mathrm{p}=0.003$ ) and, interestingly, a relationship between worse HRQoL according to CLDQ and RVR was demonstrated. Studies have shown that the occurrence of significant adverse events is related to a higher chance of SVR, and that there is an association between lower levels of hemoglobin and sustained virological response among patients with chronic hepatitis $\mathrm{C}$ treated with $\mathrm{PEG}-\mathrm{IFN}$ and ribavirin ${ }^{(29)}$.

The small sample size can be highlighted as the main limitation of the study, justified by a restrictive inclusion criteria for patients on antiviral therapy with protease inhibitors. Another limitation is that the treatment of chronic hepatitis $\mathrm{C}$ with telaprevir will soon be replaced by new direct action antiviral agents, but the understanding of the evolution of antiviral therapy in its various aspects such as efficacy, tolerance and quality of life remains relevant.

In Brazil, the approval of the second generation Direct Action Antivirals (DAA) Daclatasvir, Simeprevir and Sofosbuvir are expected in 2015. These drugs are highly efficient, have a low incidence of adverse events, and a more convenient dosage, which enables shorter treatment and eligibility of a larger number of patients ${ }^{(30)}$. Furthermore, in a recent study it was shown that the use of Sofosbuvir caused a minimal impact on HRQoL in patients undergoing antiviral therapy, demonstrating its good tolerance ${ }^{(5)}$.

\section{CONCLUSION}

According to SF-36 and CLDQ, patients undergoing double and triple therapy have reduced HRQoL indexes, but the addition of telaprevir confers a more significant decrease of HRQoL. In Brazil, the incorporation of new drugs for the treatment of patients with chronic hepatitis $\mathrm{C}$ with less impact on quality of life is pressing.

\section{RESUMO}

Objetivo: Comparar os escores de Qualidade de Vida Relacionada à Saúde (QVRS) em pacientes com hepatite crônica C submetidos à terapia antiviral dupla e tripla e analisar os possíveis fatores relacionados à QVRS. Método: A QVRS foi avaliada utilizando o Short Form 36 e o Chronic Liver Disease Questionnaire, que foram aplicados antes e nas semanas 4, 12 e 16 de tratamento, em 32 pacientes divididos em 2 grupos: terapia dupla com interferon peguilado (IFN-PEG) e ribavirina e tripla com IFN-PEG, ribavirina e telaprevir. Resultados: A redução da QVRS foi maior em pacientes em terapia tripla quando comparados àqueles tratados com duas drogas, sendo o momento mais crítico a $12^{\mathrm{a}}$ semana em ambos os grupos. Após a retirada do telaprevir, o grupo terapia tripla melhorou de modo significativo os escores de QVRS. Ansiedade e depressão no pré-tratamento, status empregatício e raça se mostraram relacionados à redução da QVRS. Conclusão: Pacientes submetidos à terapia dupla e tripla apresentam redução dos índices de QVRS, mas a adição do telaprevir confere uma queda mais expressiva.

\section{DESCRITORES}

Hepatite C; Qualidade de Vida; Terapia Combinada; Ribavirina; Interferons; Inibidores de Proteases.

\section{RESUMEN}

Objetivo: Comparar los puntajes de Calidad de Vida Relacionada con la Salud (CVRS) en pacientes con hepatitis C crónica sometidos a la terapia antiviral doble y triple y analizar los posibles factores relacionados con la CVRS. Método: La CVRS fue evaluada utilizando el Short Form 36 y el Chronic Liver Disease Questionnaire, que fueron aplicados antes y en las semanas 4, 12 y 16 de tratamiento, en 32 pacientes divididos en 2 grupos: terapia doble con interferón pegilado (IFN-PEG) y ribavirina, y triple con IFN-PEG, ribavirina y telaprevir. Resultados: La reducción de la CVRS fue mayor en pacientes en terapia triple cuando comparados con los tratados con dos drogas, siendo el momento más crítico la $12^{\text {a }}$ semana en ambos grupos. Después de la retirada del telaprevir, el grupo de terapia triple mejoró de modo significativo los puntajes de CVRS. Ansiedad y depresión en el pre tratamiento, situación de empleo y raza se 
mostraron relacionados con la reducción de la CVRS. Conclusión: Pacientes sometidos a la terapia doble y triple presentan reducción de los índices de CVRS, pero la adición del telaprevir les proporciona una caída más expresiva.

DESCRIPTORES

Hepatitis C; Calidad de Vida; Terapia Combinada; Ribavirina; El Interferones; Inhibidores de Proteasas.

\section{REFERENCES}

1. Mohd Hanafiah K1, Groeger J, Flaxman AD, Wiersma ST. Global epidemiology of hepatitis C virus infection: new estimates of age-specific antibody to HCV seroprevalence. Hepatology. 2013;57(4):1333-42.

2. Hajarizadeh B, Grebely J, Dore GJ. Epidemiology and natural history of HCV infection. Nat Rev Gastroenterol Hepatol. 2013;10(9):553-62.

3. Gower E, Estes C, Blach S, Razavi-Shearer K, Razavi H. Global epidemiology and genotype distribution of the hepatites C vírus infection. J Hepatol. 2014;61(1 Suppl):45-57.

4. Younossi ZM, Stepanova M, Mishra A, Venkatesan C, Henry L, Hunt S. The impacto $f$ chronic hepatites $C$ on resourse utilisation and inpatient mortality for medicare beneficiaries between 2005 to 2010. Aliment Pharmacol Ther. 2013;38(9):1065-75.

5. Younossi ZM, Stepanova M, Nader F, Jacobson IM, Gane E, Nelson D, et al. Patient-reported outcomes in chronic hepatites C patients with cirrhosis treated with sofosbuvir containing regimens. Hepatology. 2014;59(6):2161-9.

6. Coppola N, Pisaturo M, Sagnelli C, Sagnelli E, Angelillo IF. Peg-interferon plus ribavirin with or without boceprevir or telaprevir for HCV genotype 1: a meta-analysis on the role of response predictors. Plos One [Internet]. 2014 [cited 205 Apr 15];9(4):e94542. Available from: http://www.ncbi.nlm.nih.gov/pmc/articles/PMC3984165/

7. Cooper C, Lester R, Thorlund K, Druyts E, El Khoury AC, Yaya S, et al. Direct-acting antiviral therapies for hepatitis C genotype 1 infection: a multiple treatment comparison meta-analysis. QJM. 2013;106(2):153-63.

8. Zhu Y, Chen S. Antiviral treatment of hepatitis C virus infection and factors affecting efficacy. World J Gastroenterol. 2013:9(4):8963-73.

9. Patel AV, Wade JB, Thacker LR, Sterling RK, Siddiqui MS, Stravitz RT, et al. Cognitive reserve is a determinant of health-related quality of life in patients with cirrhosis, independent of covert hepatic encephalopathy and model for end-stage liver disease score. Clin Gastroenterol Hepatol. 2015;13(5):987-91.

10. Werkgartner G, Wagner D, Manhal S, Fahrleitner-Pammer A, Mischinger HJ, Wagner M, et al. Long-term quality of life of liver transplant recipients beyond 60 years of age. Age (Dordr). 2013;35(6):2485-92.

11. Thiele M, Askgaard G, Timm HB, Hamberg O, Gluud LL. Predictors of health-related quality of life in outpatients with cirrhosis: results from a prospective cohort. Hepat Res Treat. 2013;2013:479639. doi: 10.1155/2013/479639.

12. Chang SC, Yang SS, Chang CC, Lin CC, Chung YC, Li TC. Assessment of health-related quality of life in antiviral-treated Taiwanese chronic hepatitis C patients using SF-36 and CLDQ. Health Qual Life Outcomes. 2014;12:97.

13. Whiteley D, Elliott L, Cunningham-Burley S, Whittaker A. Health-related quality of life for individuals with hepatitis C: a narrative review. Int J Drug Policy. 2015;26(10):936-49.

14. Brasil. Ministério da Saúde; Secretaria de Vigilância à Saúde, Departamento de DST, Aids e Hepatites Virais. Protocolo Clínico e Diretrizes Terapêuticas para Hepatite Viral C e Coinfecções. Brasília; 2011.

15. Botega NJ, Bio MR, Zomignani MA, Garcia CJ, Pereira WAB. Mood disorders among medical in-patients: a validation study of hospital anxiety and depression scale (HAD). Rev Saúde Pública.1995;29(5):355-63.

16. Treanor C, Donnelly M. A methodological review of the Short Form Health Survey 36 (SF-36) and its derivatives among breast cancer survivors. Qual Life Res. 2015;24(2):339-62.

17. Ciconelli RM, Ferraz MB, Santos W, Meinão I, Quaresma MR. Q. Tradução para a língua portuguesa e validação do questionário genérico de avaliação de qualidade de vida SF-36 (Brasil SF-36). Rev Bras Reumatol. 1999;39(3):143-50.

18. Mucci S, Citero VA, Gonzalez AM, Marco MA, Nogueira-Martins LA. Cross-cultural adaptation on the Chronic Liver Disease Questionnaire (CLDQ) to the Brazilian population. Cad Saúde Pública, 2010;26(1):199-205.

19. Larrey D, Ripault MP, Pageaux GP. Patient adherence issues in the treatment of hepatitis C. Patient Prefer Adherence. 2014;8:763-73.

20. Evon DM, Golin CE, Fried MW, Keefe FJ. Chronic hepatitis C and antiviral treatment regimens: where can psychology contribute? J Consult Clin Psychol. 2013;81(2):361-74.

21. Conversano C, Carmassi C, Carlini M, Casu G, Gremigni P, Dell'Osso L. Interferon $\alpha$ therapy in patients with chronic hepatitis C infection: quality of life and depression. Hematol Rep. 2015;7(1):5632.

22. Smith-Palmer J, Cerri K, Valentine W. Achieving sustained virologic response in hepatitis C: a systematic review of the clinical, economic and quality of life benefits. BMC Infect Dis. 2015;15:19.

23. Linas BP, Barter DM, Leff JA, Assoumou SA, Salomon JA, Weinstein MC, et al. The hepatitis C cascade of care: identifying priorities to improve clinical outcomes. PloS One. 2014;9(5):e97317.

24. Mathes T, Antoine SL, Pieper D. Factors influencing adherence in Hepatitis-C infected patients: a systematic review. BMC Infect Dis. 2014; 14:203.

25. Tamori A, Kioka K, Sakaguchi H, Enomoto M, Hai H, Kawamura E, et al. Effects on anemia of drug adjustment in patients with chronic hepatitis C during telaprevir-combined therapy. Ann Hepatol. 2015;14(1):28-35. 
26. Colombo M, Fernández I, Abdurakhmanov D, Ferreira PA, Strasser SI, Urbanek P, et al. Safety and on-treatment efficacy of telaprevir: the early access programme for patients with advanced hepatitis C. Gut. 2014;63(7):1150-8.

27. Gordon SC, Muir AJ, Lim JK, Pearlman B, Argo CK, Ramani A, et al. Safety profile of boceprevir and telaprevir in chronic hepatitis C: real world experience from HCV-TARGET. J Hepatol. 2015;62(2):286-93.

28. Daltro-Oliveira R1, Morais-de-Jesus M, Pettersen KM, Paraná R, Quarantini LC. Impact of sustained virologic response on quality of life in chronic HVC carriers. Ann Hepatol. 2013;12(3):399-407.

29. Sievert W, Razavi H, Estes C, Thompson AJ, Zekry A, Roberts SK, et al. Enhanced antiviral treatment efficacy and uptake in preventing the rising burden of hepatitis C-related liver disease and costs in Australia. J Gastroenterol Hepatol. 2014;29 Suppl 1:1-9.

30. Ford N, Swan T, Beyer P, Hirnschall G, Easterbrook P, Wiktor S. Simplification of antiviral hepatitis C virus therapy to support expanded access in resource-limited settings. J Hepatol. 2014;61(1):132-8. 